\title{
Negotiation of Form, Recasts, and Explicit Correction in Relation to Error Types and Learner Repair in Immersion Classrooms
}

\author{
Roy Lyster \\ McGill University
}

\begin{abstract}
This study investigated specific patterns of a reactive approach to form-focused instruction: namely, corrective feedback and its relationship to error types and immediate learner repair. The database is drawn from transcripts of audio recordings made in four French immersion classrooms at the elementary level, totaling 18.3 hours and including 921 error sequences. The 921 learner errors were coded as grammatical, lexical, or phonological, or as unsolicited uses of L1. Corrective feedback moves were coded as explicit correction, recast, or negotiation of form (i.e., elicitation, metalinguistic clues, clarification requests, or repetition of error).
\end{abstract}

\footnotetext{
An earlier version of this paper was presented as part of a colloquium entitled "Focus on Form in Classroom Interaction" (co-organizers: J. Williams \& C. Doughty) at the Second Language Research Forum in October 1997 at Michigan State University, East Lansing. The study was funded by grants from the Social Sciences and Humanities Research Council of Canada (41094-0783) and from the Fonds pour la formation de chercheurs et l'aide à la recherche (97-NC-1409). I am grateful to the following research assistants for their participation in various phases of this study: Dawn Allen, Muriel Barret, France Bourassa, Guillaume Gentil, Lyne Laganière, Tamara Loring, and James Poirier. I am indebted to Leila Ranta for her initial collaboration on this project and her continued interest and support. I would also like to thank Carl Frederiksen for advice concerning the statistical analyses, and Birgit Harley, Patsy Lightbown, and Nina Spada for helpful comments on earlier versions of this paper.

Correspondence concerning this article may be addressed to Roy Lyster, Department of Second Language Education, McGill University, 3700 McTavish Street, Montreal, Quebec, Canada H3A 1Y2. Internet: cxrl@musica.mcgill.ca
} 
In contrast with previous studies of error treatment in L2 classrooms, which showed that teachers' use of corrective feedback was relatively unsystematic, this study revealed a certain degree of systematicity in the teachers' treatment of specific types of oral errors. First, the proportion of error types receiving corrective feedback from the teachers reflected the rate at which these various error types actually occurred. Second, the teachers tended to provide feedback on phonological and lexical errors with a certain amount of consistency (at rates of $70 \%$ and $80 \%$, respectively); grammatical errors received corrective feedback at a lower rate, but accounted for the highest number of corrective feedback moves in the database nonetheless. Third, the teachers tended to select feedback types in accordance with error types: namely, recasts after grammatical and phonological errors and negotiation of form after lexical errors.

Overall, the negotiation of form proved to be more effective at leading to immediate repair than recasts or explicit correction, particularly in the case of lexical errors and also in the case of grammatical errors and unsolicited uses of L1, but not in the case of phonological errors; the latter clearly benefit from recasts. This pattern suggests (a) that the teachers were on the right track in their decisions to recast phonological errors and to negotiate lexical errors and (b) that perhaps teachers could draw more frequently on the negotiation of form in response to grammatical errors, because almost two thirds of all grammatical repairs resulted from this type of feedback. A preference for providing feedback in this way is supported by de Bot's (1996) argument that language learners are likely to benefit more from being "pushed" (Swain, 1995) to retrieve target language forms than from merely hearing the forms in the input, because the retrieval and subsequent production stimulate the development of connections in memory. 
Corrective Feedback, Self-Repair, and Modified Output

Swain (1985) argued that learner production of modified output is necessary for second language (L2) mastery and may result from ample opportunities for output and the provision of useful and consistent feedback from teachers and peers. More recently, Swain (1995) proposed that "modified, or reprocessed, output can be considered to represent the leading edge of a learner's interlanguage" (p. 131). Pica (1988) and Pica, Holliday, Lewis, and Morgenthaler (1989) found that such modified output occurred most often when native speakers signaled an explicit need for clarification rather than provided a recast for confirmation. Although little experimental research has confirmed the effects of modified output, a study of the acquisition of past tense forms by six learners found at least short-term benefits for some learners receiving clarification requests (Nobuyoshi \& Ellis, 1993).

Some of the earliest studies of error treatment led researchers such as Allwright (1975), Corder (1967), Hendrickson (1978) and Vigil and Oller (1976) to propose that pushing learners in their output, rather than providing them with correct forms, could benefit their interlanguage development. More recently, van Lier (1988) argued that teachers should delay the use of corrective techniques that "deny the speaker the opportunity to do selfrepair, probably an important learning activity" (p. 211), and Chaudron (1988) suggested that instruction that emphasizes selfrepair in this way was more likely to improve learners' ability to monitor their own target language speech. Allwright and Bailey (1991) recommended that L2 classroom learners be allowed "both time and opportunity ... for self-repair, whether it is self- or other-initiated" (p. 107), and Calvé (1992) also recommended that teachers, rather than recasting, should give priority to peer- and self-repair and to techniques that provide learners with clues.

Notwithstanding ample support for pushing learners to modify their output during the treatment of oral errors, there is still considerable debate as to what exactly the modified output represents in terms of L2 learning and whether it is indeed necessary. 
For example, Schachter (1983) argued that neither imitation of correct forms nor the use of alternative forms following feedback provides conclusive evidence that learners take advantage of negative data. Similarly, Long (1977) cautioned against confusing the effects of corrective feedback on monitored linguistic performance with its usefulness in bringing about lasting modification of a learner's interlanguage grammar. Gass (1988) argued against the assumption that learners, with mere presentation of either implicit or explicit language information, would convert it to output; she also argued, however, that without direct or frequent negative evidence in the input, which would permit learners to detect discrepancies between their learner language and the target language, fossilization might occur. Gass and Varonis (1994) concluded from their study of dyadic interaction that interactional input provides the opportunities for learners to detect such discrepancies and "that the awareness of the mismatch serves the function of triggering a modification of existing L2 knowledge, the results of which may show up at some later point in time" (p. 299).

In communicatively oriented classrooms, however, where interactional exchanges are motivated by a variety of purposes and foci (e.g., classrooms where language is taught through content; see Harley, 1993; Swain, 1988), young L2 learners may not readily notice target-nontarget mismatches in the interactional input (Lyster, 1998). Providing learners in these contexts with signals that facilitate peer-and self-repair may draw their attention to target-nontarget mismatches more effectively than merely supplying target forms in the interactional input. That is, the retrieval of target language knowledge that results in self-repair following a teacher's metalinguistic clue or elicitation move requires more attention to the analysis of target-nontarget mismatches than does repetition of a teacher's recast or explicit correction. In this sense, different feedback types could have differential effects on learning, insofar as different types of repair entail varying degrees of attention. 
Corrective Feedback and Degrees of Explicitness

Given the nature of communicative classroom discourse, many researchers have pointed to the need to draw classroom learners' attention to form by making certain language features more salient in the input (e.g., Harley, 1993, 1994; Spada \& Lightbown, 1993; Swain, 1988). However, the question of precisely how to do so, and with what degree of explicitness, remains the centre of much debate. From a conversation analysis perspective, Seedhouse (1997) argued that teachers' preferences for implicit uses of corrective feedback mark linguistic errors as embarrassing and problematic, which in turn contradicts the pedagogical message "it's OK to make linguistic errors" (p. 567). He argued in favor of more direct and overt corrective feedback so that "pedagogy and interaction would then work in tandem" (p. 572). In a survey of more than 30 studies investigating the effects of form-focused instruction, including either direct teaching or corrective feedback, Spada (1997) concluded that an explicit focus appeared to be particularly effective in communicatively based or contentbased L2 classrooms. However, in another review of several studies concerning the role of negative evidence in classroom L2 learning, N. Ellis (1995) concluded that "provision of negative evidence, especially that which incorporates recasts ... does indeed facilitate the development of L2 syntactic ability" (p. 141; but see Lyster, 1998, for a different interpretation of these studies). Similarly, Long (1996) advocated the relatively implicit use of interactional moves, including, in addition to various input and conversational modifications, "denser than usual frequencies of semantically contingent speech of various kinds (i.e., . . . repetitions, extensions, reformulations, rephrasings, expansions and recasts), which immediately follow learner utterances and maintain reference to their meaning" (p. 452). According to the interaction hypothesis, such responses provide learners with negative evidence that in turn facilitates language development.

Two controlled studies of the effects of recasts in laboratory situations have reported some short-term benefits for adult second 
language acquisition (SLA). Long, Inagaki, and Ortega (in press) found short-term benefits for recasts over speech models (i.e., not contingent on learners' utterances) among learners of Spanish on adverb placement and among learners of Japanese on required adjective order and a preferred locative construction. Mackey and Philp (in press) compared the effects of interaction with and without recasts on the production and development of question forms. They found that advanced learners benefited more from interaction with intensive recasts than from interaction without recasts. Recasts, however, have not fared as well when compared to more explicit forms of feedback in other laboratory studies with adults. Carroll and Swain (1993) studied the effects of negative evidence on the learning of the dative alternation rule in English. The group receiving explicit metalinguistic feedback outperformed all groups, including the recast group.

It remains difficult, in any case, to know how relevant laboratory studies with adult learners may be for error treatment in communicative classrooms with young learners. A descriptive study of the various types of recasts used by teachers in contentbased classrooms (Lyster, 1998) concluded that young learners were unlikely to notice the majority of recasts in these contexts as negative evidence. The findings revealed that teachers used recasts following ill-formed learner utterances in the same ways that they use noncorrective repetition following well-formed learner utterances: ways that kept learners' attention focused on content primarily by providing confirmation or additional information related to the student's message and, to a lesser degree, by seeking confirmation or additional information. These identical discourse functions were distributed equally across recasts and noncorrective repetitions; thus, they appeared to override any corrective function that might have motivated the reformulations entailed in recasts. The corrective potential of recasts appeared to be further reduced by various signs of approval that teachers used to react to content, irrespective of well-formedness, revealing considerable ambiguity in communicative classroom discourse. 
Some of the first descriptive studies of corrective discourse in $\mathrm{L} 2$ classrooms also revealed ambiguity in the treatment of oral errors (Allwright, 1975; Chaudron, 1977; Fanselow, 1977; Long, 1977). Because recasts are used so frequently in these contexts (Calvé, 1992; Doughty, 1994; Fanselow, 1977; Lyster \& Ranta, 1997; Roberts, 1995), the implicitness inherent in their functional properties may account for much of the ambiguity (Lyster, 1998). Chaudron (1988) argued that such ambiguity constitutes one of the most noted problems with corrective feedback: teachers' semantically contingent responses can serve several functions, of either a positive or negative nature (correcting, agreeing, appreciating, etc.), thus leading to a problem for L2 learners for whom "the modification may be imperceptible, or perceived as merely an alternative" (p. 145).

Large-scale descriptive studies have also reported the observation of ambiguous error treatment in L2 classrooms (Allen, Swain, Harley, \& Cummins, 1990; Netten, 1991). Several other studies have provided evidence that, for corrective feedback to be effective (i.e., not ambiguous), relatively explicit signals were employed. For example, some studies have revealed in post hoc analyses of classroom interaction that effective corrective feedback, which allowed learners' attention to be drawn to their errors, was accompanied by explicit paralinguistic signals (Lightbown, 1991; Lightbown \& Spada, 1990) or entailed a reduction of the learner's utterance with added stress for emphasis (Chaudron, 1977). Still other studies have operationalized corrective feedback a priori as having a more explicit focus than recasts alone can provide. For example, in Doughty and Varela's (1998) study, the teacher's repetition of the learner's error preceded the recast so as to highlight the target-nontarget mismatch. Similarly, in Tomasello and Herron's $(1988,1989)$ studies, teachers provided recasts that were, as Long (1996) argued, "delivered in the form of explicit correction" and "accompanied by opportunities for unhurried visual inspection and cognitive comparison" (p. 441). 


\section{Preceding Study}

In Lyster and Ranta (1997), we presented an analysis of classroom interaction that allowed us to characterize various types of corrective feedback used by teachers in response to learner errors. We discerned six main feedback moves in the database:

1. Explicit correction: teacher supplies the correct form and clearly indicates that what the student had said was incorrect;

2. Recasts: teacher implicitly reformulates all or part of the student's utterance;

3. Elicitation: teacher directly elicits a reformulation from students by asking questions such as "Comment ça s'appelle?" or "How do we say that in French?" or by pausing to allow students to complete teacher's utterance, or by asking students to reformulate their utterance;

4. Metalinguistic clues: teacher provides comments, information, or questions related to the well-formedness of the student's utterance such as "Ça ne se dit pas en français" or " $C$ 'est masculin?";

5. Clarification requests: teacher uses phrases such as "Pardon?" and "I don't understand";

6. Repetition: teacher repeats the student's ill-formed utterance, adjusting intonation to highlight the error.

The percentage distribution of the six feedback types was: recasts $55 \%$, elicitation $14 \%$, clarification requests $11 \%$, metalinguistic clues $8 \%$, explicit correction $7 \%$, and repetition of error $5 \%$. Recasts were by far the most widely used technique, accounting for over half of all feedback moves.

We examined not only the distribution of different feedback types but also the ways in which learners reacted to the different types of feedback in turns immediately following corrective feedback. We referred to such reactions as learner uptake and coded 
these utterances as either repaired or still in need of repair. We borrowed the notion of uptake from speech act theory (Austin, 1962); it allowed us to account for a variety of learner reactions in response to the teachers' apparent intentions and also to quantify the students' productive role as participants in the corrective discourse. ${ }^{1}$

The findings revealed that recasts resulted in the lowest rate of uptake-including the lowest rate of repair. More importantly, neither recasts nor explicit correction led to any peer-or self-repair because they already provide correct forms to learners. In contrast, elicitation, metalinguistic clues, clarification requests, and repetition of error not only led to higher rates of uptake but all were able to elicit peer- and self-repair. We thus regrouped these 4 interactional moves under the rubric of negotiation of form and distinguished them from recasts and explicit correction in that they provide learners with signals that facilitate peer- and self-repair rather than with mere rephrasings of their utterances.

We considered the term negotiation of form to capture more accurately than negotiation of meaning the ways in which teachers focused on form during meaningful interaction (see Lyster, 1994). In contrast to the latter's primarily conversational function, aimed "to resolve communication breakdowns and to work toward mutual comprehension" (Pica et al., 1989, p. 65), we attributed to the negotiation of form a more didactic function: namely, "the provision of corrective feedback that encourages self-repair involving accuracy and precision and not merely comprehensibility" (Lyster \& Ranta, 1997, p. 42). We concluded that the negotiation of form provided learners with timely opportunities to make important form-function links in the target language without interrupting the flow of communication and while maintaining the mutuality inherent in negotiation. That is, when teachers used either metalinguistic clues, elicitation, repetition of error, or clarification requests, they returned the floor to students along with cues for the latter to draw on their own resources, thus allowing for negotiation to occur bilaterally. Conversely, there appeared to be little to 
negotiate between teacher and student when the teacher provided either recasts or explicit corrections.

We speculated that the negotiation of form, allowing for peerand self-repair, might benefit L2 learning in at least two ways: (a) by providing opportunities for learners to proceduralize target language knowledge already internalized in declarative form (cf. Hulstijn, 1990; McLaughlin, 1990; Nobuyoshi \& Ellis, 1993; Towell, Hawkins, \& Bazergui, 1996) and (b) by drawing learners' attention to form during communicative interaction in ways that allowed them to re-analyze and modify their nontarget output as they tested new hypotheses about the target language (Pica et al., 1989; Swain, 1993, 1995).

Recasts and explicit correction are thus distinguishable from the negotiation of form in that the former supplies correct forms that learners may or may not repeat, whereas the latter provides signals to facilitate peer- and self-repair. In terms of explicitness, whereas recasts are clearly distinguishable from explicit corrections, it remains difficult to characterize the negotiation of form in this respect; to do so will require further analysis of each of these moves in the database as well as experimentally designed studies. It is likely the case, for example, that teachers' metalinguistic clues or repetition of learner errors are relatively explicit in relation to clarification requests and that, overall, the four interactional moves comprising the negotiation of form are more explicit than most recasts and more implicit than explicit corrections.

\section{Research Questions}

The present study compares the extent to which teachers use negotiation of form, recasts, and explicit correction to respond to specific error types then examines which types of errors are immediately repaired as a result of each feedback type. The study was designed to describe these relationships as detected in transcripts of classroom interaction in four French immersion classrooms at the elementary level. The study draws on the database and error treatment model presented by Lyster and Ranta (1997) 
and aims to answer two research questions not examined in that study:

1. What types of learner errors lead to what types of corrective feedback?

2. What types of corrective feedback lead to the immediate repair of what types of learner errors?

\section{Method}

\section{Database}

The database includes 27 lessons, totaling 1,100 minutes or 18.3 hours, taught by 4 French immersion teachers at the Grade $4 / 5$ level. Teacher 3 (T3) ${ }^{2}$ teaches in an early total immersion program; Teachers 4,5 , and 6 (T4, T5, T6) teach in a mid-immersion program beginning at Grade 4 . The data analyzed include 13 French language arts lessons (7.8 hours) and 14 subject-matter lessons (10.5 hours) including lessons from science, social studies, and math. The breakdown of the 27 lessons across the 4 teachers, including the date, duration, and topic of each lesson, appears in Appendix A.

The lessons we selected for analysis did not include formal grammar or spelling lessons; instead, they represented a more communicative orientation, occurring either during subjectmatter classes or French language arts with a thematic focus. We had not instructed the 4 teachers to use any particular kinds of feedback nor to focus on any particular type of error. We asked them to continue with their usual way of teaching as we observed and tape-recorded; they knew only that we were interested in recording classroom interaction. They continued with their regular program while we made recordings and while one or more observers coded classroom activities using Part A of the Communicative Orientation to Language Teaching (COLT) coding scheme (Spada \& Fröhlich, 1995), which we had adapted for use in immersion classrooms. The purpose of the COLT coding scheme 
was twofold: first, to provide a breakdown of classroom activities and episodes, and second, to provide information concerning the overall communicative orientation of the 4 classrooms (these results are in Fazio \& Lyster, 1997).

The recordings were transcribed by a native speaker (NS) or native-like speaker of French and then verified at least once by a second transcriber who was again either an NS or native-like speaker of French. Following Doughty (1994), we imported the transcripts selected for analysis into COALA (Computer Aided Linguistic Analysis; Thornton \& Pienemann, 1994) which allowed $1 \mathrm{NS}$ and 2 native-like speakers of French to code and quantify the data using our user-defined coding categories pertaining to error types, feedback types, and learner repair. ${ }^{3}$

\section{Data Analysis}

The analytic model used to code the interactional data, adapted from Lyster and Ranta (1997), appears in Figure 1. The sequence begins with a learner's utterance containing at least one error. The nontarget utterance is followed either by the teacher's corrective feedback or not; if not, then there is topic continuation. If corrective feedback is provided by the teacher, then it is either followed by uptake on the part of the student or not (no uptake entails topic continuation). If there is uptake, then the student's nontarget utterance is either repaired or continues to need repair in some way. If the utterance needs repair, then the teacher may again provide corrective feedback; if no further feedback is provided, then there is topic continuation. If and when there is repair, then it is followed either by topic continuation or by some repair-related sign of approval from the teacher. ${ }^{4}$ Following approval there is topic continuation.

The model takes into account 4 main error types: grammatical, phonological, lexical, and unsolicited uses of the first language (L1). The latter, of course, are not errors per se, but we were interested in examining, particularly in immersion classrooms, teachers' reactions to uses of L1. Errors generally included 


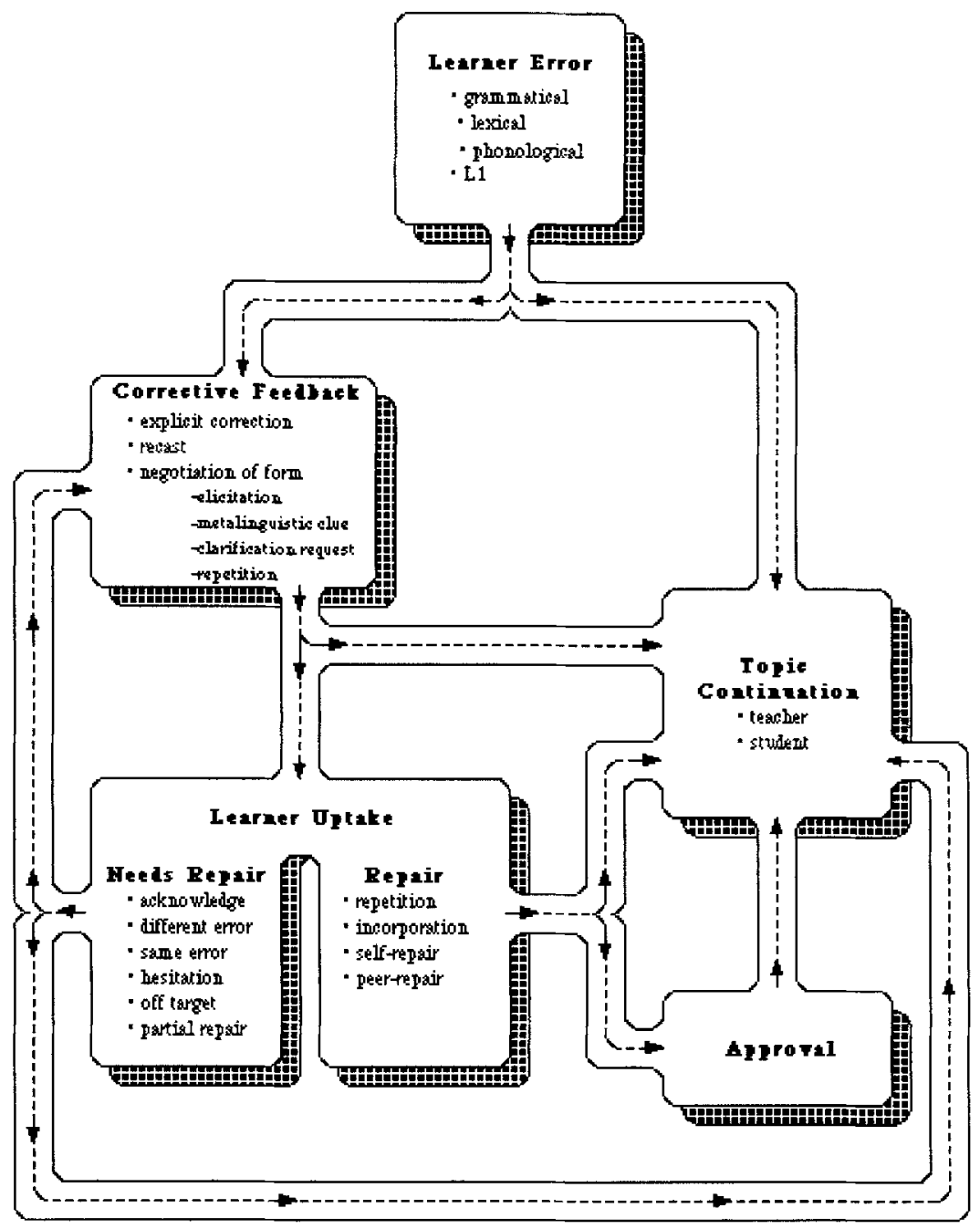

Figure 1. Error treatment sequence (From "Corrective Feedback and Learner Uptake: Negotiation of Form in Communicative Classrooms," by R. Lyster and L. Ranta, 1997, Studies in Second Language Acquisition. Copyright 1997 by Cambridge University Press. Adapted with permission.) 
nonnative-like uses of French, although we also took into account utterances which could be considered native-like for young children, but which teachers considered substandard in some way (e.g., lexically imprecise or sociolinguistically inappropriate). Because of our research interest in focus-on-form, we did not analyze errors related to content. A description of the error types follows:

\section{Grammatical errors.}

1. Errors in the use of closed classes such as determiners, prepositions, and pronouns.

2. Errors in grammatical gender (including wrong determiners and other noun/adjective agreements).

3. Errors in tense, verb morphology, auxiliaries (including avoir and être distinctions), and subject/verb agreement.

4. Errors in pluralization, negation, question formation, relativization, and word order.

Classification of some of the foregoing features as grammatical rested on our decision to consider errors in closed classes as grammatical and errors in open classes as lexical; for example, we thus coded prepositions as grammatical.

\section{Lexical errors.}

1. Inaccurate, imprecise, or inappropriate choices of lexical items in open classes-namely, nouns, verbs, adverbs, and adjectives (e.g., adoption for adaptation, pancarte for carte, imaginatif for imaginaire, petite aile for aileron, déodorant for malodorant, demander une question for poser une question, rapetissement for réduction, coulisses for canaux, réussir for recevoir, grosseur for longueur, un petit bout de l'eau for une petite goutte d'eau, brisures for biscuits, rouge for roux, tomber for couler, mangeur for rongeur);

2. Nontarget derivations of nouns, verbs, adverbs and adjectives, involving incorrect use of prefixes and suffixes (e.g., 
odoreux for odorant, piques for piquants, le déplace for le déplacement, un tonne for un tonneau).

Phonological errors.

1. Decoding errors as students read aloud (e.g., aussi for assis, livre for lièvre, ce sera for ce serait, final consonants pronounced in coup and bond);

2. Mispronunciations resulting from particularities of the French sound system (e.g., the " $u$ " in grue pronounced as $/ \mathrm{u}$, son pronounced as sans);

3. Absence of obligatory elision (e.g., le éléphant, le autre, de un demi tour);

4. Absence of obligatory liaison (e.g., en/ondes);

5. Pronunciation of silent letters (e.g., the " $\mathrm{f}$ " in oeufs, the "s" in vers);

6. Addition of other elements (météro for météo, réalisastrice for réalisatrice) or omission of obligatory ones (e.g., jadis pronounced without the final consonant, la fuit for la fuite, météologie for météorologie).

Unsolicited uses of $L 1$.

1. Instances where students used English when French would have been more appropriate and expected; we excluded from this category, of course, uses of L1 solicited by the teacher (e.g., "Comment dit-on 'marmotte' en anglais?") or students' framing their use of L1 metalinguistically ("Comment dit-on 'computer' en français?").

In Lyster and Ranta (1997) we also used the category multiple for coding student turns containing more than one type of error. However, for the present study, I deleted this category and recoded the $14 \%$ of student turns containing more than one error type so as to reflect the most prominent error type or, in cases where corrective feedback was provided, to reflect the error type on which 
the teacher's feedback focused. Although classifying learners' errors is at best a flawed procedure, the above definitions provided the 3 coders with guidelines sufficiently clear to allow them to discuss ambiguous cases until they agreed. A fourth researcher, a French NS who had learned the foregoing coding criteria, coded a subset of $15 \%$ of the data, including 140 randomly selected error sequences; a post hoc test of interrater reliability yielded a .84 level of agreement.

The present study examined the 4 error types in relation to the 3 main feedback types (i.e., negotiation of form, recasts, and explicit correction) and in relation to learner repair. As in Lyster and Ranta's (1997) study, repair here refers to the correct reformulation of an error as uttered in a single student turn, not to the sequence of turns resulting in the correct reformulation; nor does it refer to self-initiated repair. We did not analyze unprompted self-corrections; instead, we analyzed only prompted repairs-what Schegloff, Jefferson, and Sacks (1977) called "otherinitiated" repair. We found 4 types of other-initiated repair, including the student's (a) repetition or (b) incorporation of the teacher's reformulation, or student-generated repairs in the form of (c) peer- and (d) self-repair. The needs-repair category included student utterances coded as acknowledgments (such as "yes" or "no" in response to teacher feedback), hesitations, same or different errors, partial repairs, or "off-target." The needs-repair category could lead to additional feedback from the teacher and thus allowed for error treatment sequences to go beyond the third turn (as in example 2 in Appendix B). If there was no uptake following the teacher's corrective feedback move (neither "repair" nor "needs-repair"), then either teacher or student initiated topic continuation. The 6 examples of error treatment sequences in Appendix B illustrate the various coding categories. ${ }^{5}$

\section{Results}

The analysis yielded a total of 921 error sequences, each initiated by a student turn containing at least one error coded as 
grammatical, lexical, phonological, or L1. Of these 921 turns with error or L1, 558 (61\%) were followed by a teacher's turn containing corrective feedback coded as either negotiation of form, recast, or explicit correction. The remaining 363 (39\%) student turns with error or L1 were immediately followed by topic-continuation moves. Of the 558 corrective feedback moves, 186 (33\%) led to learner repair within the error treatment sequence. Of the 186 repairs, 140 immediately followed the teacher's initial feedback move; the remaining 46 were preceded by additional feedback that resulted from one or more student turns coded as needs-repair. ${ }^{6}$

Table 1 presents the distribution of error types in the entire database: $50 \%$ were grammatical, $18 \%$ were lexical, $16 \%$ were phonological, and $16 \%$ were unsolicited uses of $\mathrm{L} 1$. Table 2 reveals the distribution of corrective feedback across the different error types: $46 \%$ of all feedback followed grammatical errors, $24 \%$ followed lexical errors, $19 \%$ followed phonological errors, and $11 \%$ followed uses of L1. Thus, as portrayed graphically in Figure 2, the proportion of error types receiving teachers' corrective feedback

Table 1

Number and Percentage of Errors $(N=921)$ by Error Type

\begin{tabular}{lll}
\hline Grammatical & 457 & $(50 \%)$ \\
Lexical & 167 & $(18 \%)$ \\
Phonological & 148 & $(16 \%)$ \\
L1 & 149 & $(16 \%)$ \\
\hline
\end{tabular}

Table 2

Number and Percentage of Feedback Moves $(N=558)$ per Error Type

\begin{tabular}{lrl}
\hline Grammatical & 257 & $(46 \%)$ \\
Lexical & 133 & $(24 \%)$ \\
Phonological & 104 & $(19 \%)$ \\
L1 & 64 & $(11 \%)$ \\
\hline
\end{tabular}




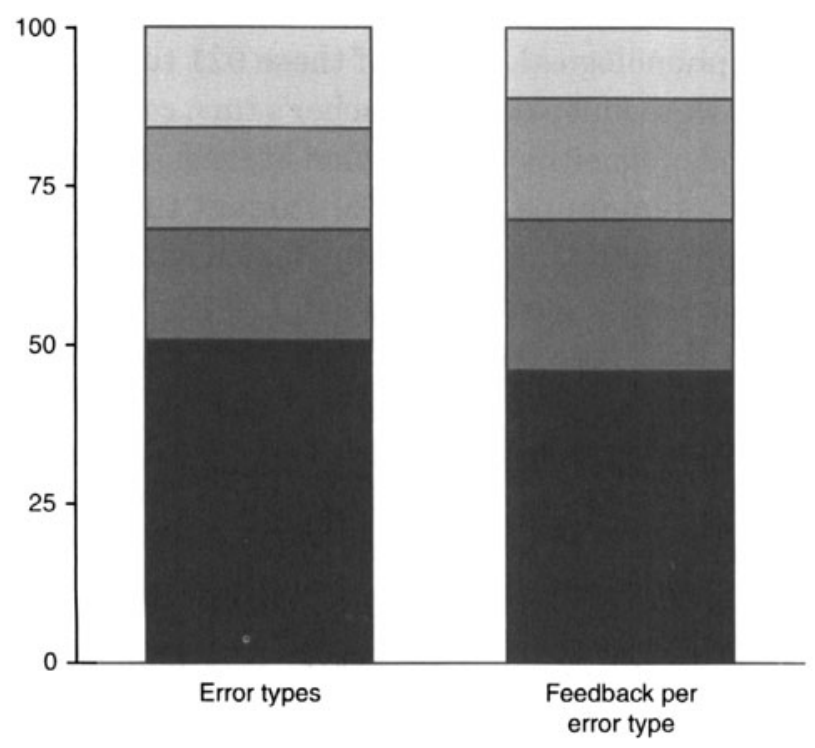

L1

Phonological

Lexical

Grammatical

Figure 2. Percentage distribution of error types and feedback per error type

reflects the rate at which these various error types occur in the database.

Table 3 reveals the rate at which each error type received corrective feedback: $80 \%$ of lexical errors, $70 \%$ of phonological errors, $56 \%$ of grammatical errors, and only $43 \%$ of uses of L1. This analysis combined data from language arts and subject-matter lessons because similar patterns were apparent in these 2 types of lessons: In French language arts, corrective feedback followed $78 \%$ of lexical errors, $74 \%$ of phonological errors, $58 \%$ of grammatical errors, and $53 \%$ of utterances in $\mathrm{L} 1$; in subject-matter classes, corrective feedback followed $81 \%$ of lexical errors, $63 \%$ of phonological errors, $55 \%$ of grammatical errors, and $40 \%$ of utterances in L1 (cf. Chaudron, 1986). ${ }^{7}$

The 558 feedback moves following initial errors were distributed across the 3 feedback types as follows: $334(60 \%)$ were recasts, $190(34 \%)$ involved negotiation of form, and $34(6 \%)$ were explicit corrections. $^{8} \mathrm{~A}$ comparison of the distribution of these feedback types across different error types appears in Table 4 and Figure 3. 
Table 3

Rate of Feedback per Error Type

\begin{tabular}{lrll}
\hline Lexical & $133 / 167$ & & $80 \%$ \\
Phonological & $104 / 148$ & $=$ & $70 \%$ \\
Grammatical & $257 / 457$ & $=$ & $56 \%$ \\
L1 & $64 / 149$ & $=$ & $43 \%$ \\
\hline
\end{tabular}

Table 4

Distribution of Errors Receiving Feedback $(N=558)$ Across Feedback Types and Error Types

\begin{tabular}{lrccr}
\hline & $\begin{array}{c}\text { Grammatical } \\
(n=257)\end{array}$ & $\begin{array}{c}\text { Lexical } \\
(n=133)\end{array}$ & $\begin{array}{c}\text { Phonological } \\
(n=104)\end{array}$ & $\begin{array}{c}\text { L1 } \\
(n=64)\end{array}$ \\
\hline Explicit correction & $3(1 \%)$ & $10(7 \%)$ & $13(13 \%)$ & $8(12 \%)$ \\
Recast & $185(72 \%)$ & $50(38 \%)$ & $67(64 \%)$ & $32(50 \%)$ \\
Negotiation of form & $69(27 \%)$ & $73(55 \%)$ & $24(23 \%)$ & $24(38 \%)$ \\
\hline
\end{tabular}

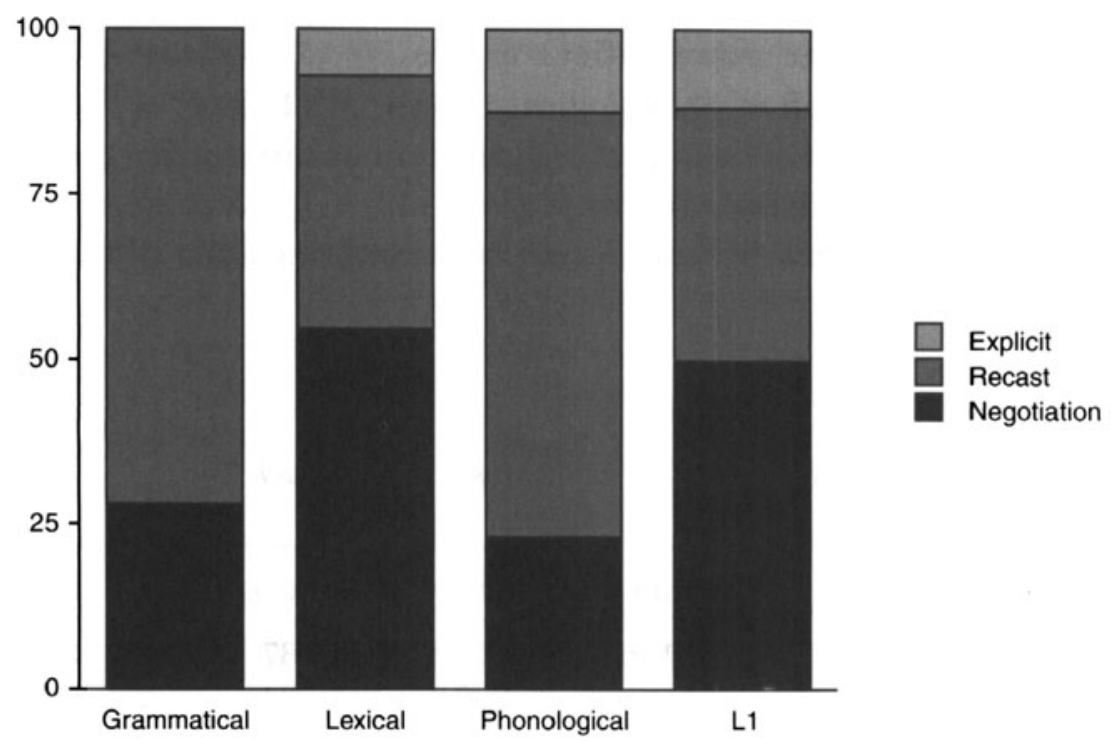

Figure 3. Percentage distribution of feedback types across error types 
The majority of feedback moves following phonological and grammatical errors were recasts ( $64 \%$ and $72 \%$, respectively); the majority following lexical errors involved negotiation of form (55\%). When corrective feedback followed use of L1 (recall the small number of unsolicited uses of $\mathrm{L} 1$ receiving feedback), $50 \%$ were translation equivalents (coded as recasts); another $38 \%$ were negotiated.

A loglinear analysis of a $2 \times 4$ contingency table (Table 5) tested the effects of these cross-classified categorical data and their interaction (feedback type by error type). The analysis excluded explicit corrections due to their rarity ( $6 \%$ of all feedback moves), resulting in a comparison of feedback type with 2 levels (recasts vs. negotiation of form) and error type with 4 levels. The main effect of feedback type was significant, $\chi^{2}(1,524)=38.54$, $p<.0001$, as was the main effect of error type, $\chi^{2}(3,524)=152.25$, $p<.0001$. The interaction between feedback type and error type was significant, $\chi^{2}(3,524)=41.53, p<.0001$, confirming that error type affected choice of feedback. Pairwise analyses of the 3 most frequent error types revealed that the teachers' choice of feedback after lexical errors differed significantly from their choice of feedback after grammatical errors, $\chi^{2}(1,377)=36.14$, $p<.0001$, and after phonological errors, $\chi^{2}(1,214)=23.61$, $p<.0001$; their feedback preferences did not differ after grammatical and phonological errors, $\chi^{2}(1,345)=.02$. A comparison of feedback choice for each error type confirmed the different

Table 5

Contingency Table for Loglinear Analysis of Feedback Type by Error Type

Grammatical Lexical Phonological L1 Total

\begin{tabular}{lrrrrr}
\hline Recast & 185 & 50 & 67 & 32 & 334 \\
Negotiation of form & 69 & 73 & 24 & 24 & 190 \\
Total & 254 & 123 & 91 & 56 & 524 \\
\hline
\end{tabular}


patterns: Negotiation of form was significantly more likely than recasts to follow lexical errors, $\chi^{2}(1,123)=4.25, p<.05$, whereas recasts were significantly more likely than negotiation of form to follow grammatical errors, $\chi^{2}(1,254)=48.88, p<.0001$, and phonological errors, $\chi^{2}(1,91)=18.62, p<.0001$.

Table 6 gives the number and percentage of repairs per error type. Phonological errors had the highest rate of repair: $62 \%$ of the 104 phonological errors receiving feedback were repaired. The next highest rate of repair was for lexical errors: Of the 133 lexical errors with feedback, $41 \%$ were repaired. Only $22 \%$ of the 257 grammatical errors with feedback were repaired, and only $17 \%$ of the unsolicited uses of L1 with feedback were repaired.

As can also be seen in Table 6, the 186 repairs in the database were distributed evenly across phonological, grammatical, and lexical errors: 64 , 55, and 56, respectively; only 11 were for L1 repairs. Examining the relationships among error type, feedback type, and repair, I excluded these negligible $L 1$ repairs. These results are displayed in Table 7 and Figure 4. Of the grammatical repairs, $61 \%$ resulted from the negotiation of form and $34 \%$ from recasts, thus inversely reflecting the occurrence of these 2 feedback types. That is, although the majority of the feedback following grammatical errors involved recasts, the majority of grammatical repairs followed the negotiation of form. Conversely, lexical and phonological repairs resulted, for the most part, from the different feedback types that these error types tended to invite. Thus $80 \%$ of lexical repairs were due to the negotiation of form and $61 \%$ of phonological repairs followed recasts.

Table 6

Number and Percentage of Repairs of Errors with Feedback

Phonological $(n=104)$

$64(62 \%)$

Lexical $(n=133)$

$55(41 \%)$

Grammatical $(n=257)$

$56(22 \%)$

$\mathrm{L} 1(n=64)$

$11(17 \%)$ 
Table 7

Distribution of Grammatical, Lexical, and Phonological Repairs Across Feedback Types

\begin{tabular}{|c|c|c|c|}
\hline & $\begin{array}{c}\text { Grammatical } \\
\text { repairs } \\
(n=56)\end{array}$ & $\begin{array}{l}\text { Lexical } \\
\text { repairs } \\
(n=55)\end{array}$ & $\begin{array}{c}\text { Phonological } \\
\text { repairs } \\
(n=64)\end{array}$ \\
\hline Explicit correction & $3(5 \%)$ & $3(5 \%)$ & $10(16 \%)$ \\
\hline Recast & $19(34 \%)$ & $8(15 \%)$ & $39(61 \%)$ \\
\hline Negotiation of form & $34(61 \%)$ & $44(80 \%)$ & $15(23 \%)$ \\
\hline
\end{tabular}

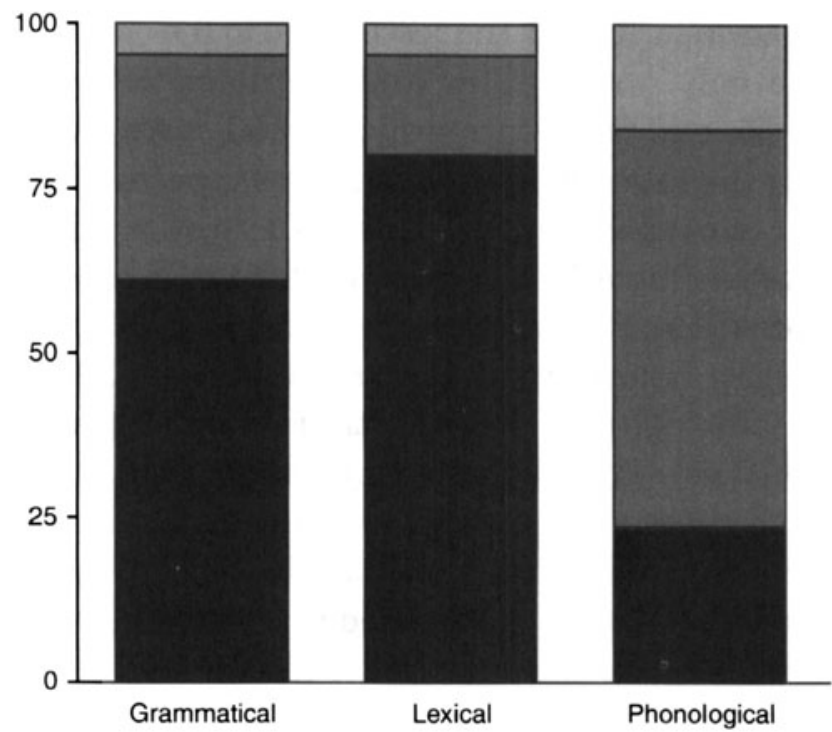

$\square$ Explicit Recast Negotiation

Figure 4. Percentage distribution of grammatical, lexical, and phonological repairs across feedback types

A loglinear analysis of a $2 \times 3$ contingency table (Table 8 ) tested the effects and interaction of feedback type ( 2 levels: recasts and negotiation of form) by repaired-error type (3 levels: grammatical, lexical, and phonological). The analysis again excluded explicit corrections due to their rarity. The main effect of feedback 
Table 8

Contingency Table for Loglinear Analysis of Repaired-Error Type by Feedback Type

\begin{tabular}{lcccr}
\hline & $\begin{array}{c}\text { Grammatical } \\
\text { repairs }\end{array}$ & $\begin{array}{c}\text { Lexical } \\
\text { repairs }\end{array}$ & $\begin{array}{c}\text { Phonological } \\
\text { repairs }\end{array}$ & Total \\
\hline Recast & 19 & 8 & 39 & 66 \\
Negotiation of form & 34 & 44 & 15 & 93 \\
Total & 53 & 52 & 54 & 159 \\
\hline
\end{tabular}

type was significant, $\chi^{2}(1,159)=4.54, p<.05$, indicating that significantly more repairs overall resulted from the negotiation of form than from recasts. The main effect of repaired-error type was not significant, $\chi^{2}(1,159)=.04$, reflecting the equal distribution of error types across repairs, although there was a significant interaction between feedback type and repaired-error type, $\chi^{2}(2$, $159)=38.18, p<.0001$. Comparisons of the two feedback types for each type of repaired error revealed the following significant differences: Negotiation of form was significantly more likely than recasts to precede lexical repairs, $\chi^{2}(1,52)=19.67, p<.0001$, and grammatical repairs, $\chi^{2}(1,53)=4.13, p<.05$, whereas recasts were significantly more likely than negotiation of form to precede phonological repairs, $\chi^{2}(1,54)=9.89, p<.002$.

\section{Discussion}

The foregoing results provide the following answers to the two research questions.

1. What types of learner errors lead to what types of corrective feedback? Grammatical and phonological errors tended to invite recasts, whereas lexical errors tended to invite negotiation of form more often than recasts.

2. What types of corrective feedback lead to the immediate repair of what types of learner errors? The majority of 
phonological repairs were learner repetitions following recasts and the majority of grammatical and lexical repairs were peerand self-repairs following negotiation of form.

The findings suggest that the 4 teachers provided corrective feedback somewhat more consistently and less randomly than teachers observed in previous studies (e.g., Allen et al., 1990; Fanselow, 1977). In the present study, the teachers' treatment of oral errors showed some degree of systematicity in at least 3 ways. First, the proportion of error types receiving corrective feedback from these teachers reflected the rate at which these various error types occurred (cf. Chaudron, 1988). ${ }^{9}$ Second, the teachers tended to provide corrective feedback on phonological and lexical errors with a certain degree of consistency-at rates of $70 \%$ and $80 \%$ respectively. ${ }^{10}$ Third, the teachers tended to select feedback types in accordance with error types: namely, recasts after grammatical and phonological errors and negotiation of form after lexical errors.

The following discussion takes account of only 3 types of errors (grammatical, lexical, and phonological) and 2 types of corrective feedback (negotiation of form and recasts), thus excluding learner utterances in L1 as well as feedback coded as explicit correction. The latter occurred only rarely in comparison to recasts and the negotiation of form. ${ }^{11}$ Similarly, it remains difficult to discern any pattern in uses of $\mathrm{L} 1$, because of the particularly low rate of feedback following them. When there was feedback, translation equivalents, coded as recasts, tended to predominate. More noteworthy, and somewhat unexpected, was the teachers' high tolerance for uses of $\mathrm{L} 1$ and low expectation that they should be "repaired." This may be due, in part, to 3 of the 4 classes being in only their first year of a mid-immersion program.

About half of the phonological errors were decoding errors committed as students read aloud, thus reducing the potential that students would perceive recasts ambiguously. ${ }^{12} \mathrm{~A}$ recast following a phonological error during a reading activity would be perceptually salient as well as unequivocal in terms of purpose; a 
student probably could not perceive such a recast as an alternative yet equally correct variant. Other phonological errors entailed distinctive features of the French sound system. Such pronunciation errors were perhaps not amenable to negotiation and instead required correct models for learners to imitate. Indeed, the unusually high rate of repair following teachers' recasts of phonological errors suggested that students did indeed notice the corrective intentions underlying the teacher's recast, in that they tended to repeat it and get it right.

Teachers demonstrated a low tolerance for lexical errors and a preference to react to such errors by using negotiation of form to incite students to produce, on their own, the correct form. They may have done so because recasts of lexical errors, in contrast to recasts of phonological errors, risk being perceived by learners as alternative yet equally correct forms. Similar findings have been noted in L1 contexts. For example, Marcus (1993) argued that recasts do not indicate whether the corrective reformulation is simply a stylistic variant or synonym, or whether the learner's utterance is unacceptable. Because L2 teachers frequently provide learners with synonyms as they strive to provide rich and varied input, recasts of some lexical errors risk being ambiguously perceived by students as acceptable alternatives. Aware of such potential ambiguity in the case of lexical errors, the teachers may have tended to provide signals to prompt students rather than provide them with correct forms. Furthermore, the teachers may have pushed students in their lexical development because they believed that students can in fact be pushed in this respect. Our own observations confirmed the teachers had first-hand experience in observing students successfully self-repair lexical items and subsequently employ them as an intrinsic part of the same lesson.

In contrast, grammatical errors were repaired at a lower rate than lexical errors and tended to recur within the same lesson in spite of corrective feedback, thus reflecting different degrees of complexity in the processing of lexical and grammatical repairs. That is, the cognitive processes involved in accessing and applying 
the system-driven rules of grammar are more complex than those involved in the retrieval of lexical items. This may in turn explain why the teachers demonstrated a clear preference for recasting grammatical errors. They perhaps hesitated to use negotiation of form in response to grammatical errors, because grammatical knowledge involves complex system-driven rules that might not be easily retrievable, were perhaps not yet internalized, and were only rarely intrinsic to the propositional content of the lesson, unlike lexical errors. The teachers may have suspected that recasting would be more appropriate, providing them with efficient ways of advancing the lesson by keeping students' attention focused on content in spite of gaps in L2 proficiency.

However, notwithstanding the teachers' preference for recasting grammatical errors, only about one-third of the grammatical repairs followed recasts; almost two-thirds were peer- and (mainly) self-repairs following the negotiation of form. Because it pushes them to modify their output themselves, the negotiation of form incites learners first to notice their nontarget output and then, in Swain's (1995) terms, to reprocess the nontarget output. Conversely, recasts may be less successful at drawing learners' attention to their nontarget output-at least in content-based classrooms where recasts risk being perceived by young learners as alternative or identical forms fulfilling discourse functions other than corrective ones. Along with frequent noncorrective repetition in classroom discourse, recasts tend to provide or seek confirmation or additional information related to the learner's message (Lyster, 1998). Thus, recasts of grammatical errors probably do not provide young classroom learners with negative evidence, in that they fail to convey what is unacceptable in the L2. Instead, recasts may serve as positive evidence, in the same way that noncorrective repetitions do, in that they provide learners with exemplars of what is possible in the language. As Morgan, Bonamo, and Travis (1995) argued, recasts do not inform children how to formulate appropriate grammatical modifications any more than do other forms of positive evidence. 
In summary, this study has described and sought to explain at least 2 noteworthy patterns in the 4 classrooms examined:

Pattern 1. Teachers tended to recast grammatical and phonological errors and to negotiate lexical errors. This overall pattern initially called into question the term negotiation of form, which seemed inappropriate if the negotiation was primarily about lexical items. However, Pattern 2 subsequently revealed some promising effects for the negotiation of form in response to grammatical errors.

Pattern 2. Phonological repairs tended to follow recasts, whereas grammatical and lexical repairs tended to follow the negotiation of form. This pattern suggests (a) that the teachers were on the right track in their decisions to recast phonological errors and to negotiate lexical errors and (b) that perhaps teachers could draw more frequently on the negotiation of form in response to grammatical errors, because almost two-thirds of all grammatical repairs resulted from this type of feedback.

The effects of such interactional moves on L2 learning, however, clearly require assessment in carefully designed, experimental classroom studies before one can make claims for their effectiveness. The present findings may contribute to the design of experimental studies intended to manipulate the corrective feedback types and related patterns described here. In addition to its distinguishing chararacterstic of eliciting peer- and self-repair, as proposed by Lyster and Ranta (1997), the negotiation of form exhibited further distinctiveness in the present study by the types of errors it tends to follow (i.e., lexical) and by the types of errors that get repaired as a result of it (i.e., lexical and grammatical). These findings support the view that the negotiation of form constitutes a distinguishable set of feedback moves used by teachers and merits, therefore, further research to determine its effect on the development of target language accuracy. 


\section{Notes}

${ }^{1}$ We used the term uptake very differently from other classroom SLA research where it has referred to what learners report having learned from a particular lesson (e.g., Allwright, 1984; R. Ellis, 1995; Slimani, 1992). From a discourse perspective, we prefer to refer to such explicit formulations of the effect or perlocutionary force of a speech event as upshot (e.g., Cook, 1989, p. 40).

${ }^{2}$ Teachers 1 and 2, Grade 6 teachers, are not included in this part of the study. The labels T3, T4, T5, and T6 are used in this paper to maintain consistency throughout other reports deriving from this study.

${ }^{3}$ More detailed descriptions of the data collection procedures can be found in Lyster and Ranta (1997, pp. 42-43).

${ }^{4}$ These moves included at least one of 3 types of approval, occurring either alone or in various combinations: (1) simple affirmation or acknowledgement (e.g., oui; OK; bien sûr); (2) praise markers (e.g., Très bien; Excellent; Bravo!); (3) repetition of the student's repair (which could also include additional metalinguistic information or commentary; see Lyster, 1998).

${ }^{5}$ The following conventions are used in the examples: $\mathrm{St}=$ student; $\mathrm{Sts}=$ more than one student; Stdif $=$ a different student from the previous student turn. Overlapping speech is indicated by $\%$.

${ }^{6}$ In these 46 cases, we counted the feedback type used by the teacher in the move immediately preceding the repair.

${ }^{7}$ Chaudron's (1986) study of error treatment in immersion classrooms found that $77 \%$ of grammatical errors received corrective feedback in French language arts classes, compared to only $37 \%$ in subject-matter classes. The finding that teachers in the present study provided corrective feedback at similar rates whether teaching language arts or subject matter may be due to the "whole language approach" they adopted. This approach minimizes explicit language instruction and aims to integrate language skills across disciplines. The teachers were so adept at blurring the borders between language classes and content classes that we often had to ask which we were observing.

${ }^{8}$ This percentage distribution differs slightly from that reported in Lyster and Ranta (1997) because the present study took account of errors initiating each sequence but not of subsequent learner utterances coded as "needs-repair." ${ }^{9}$ In his synthesis of 5 different studies, Chaudron (1988, pp. 140-41) found an inverse relationship between errors produced and errors treated: The more often a particular error was made, the less likely the teachers were to provide feedback. It remains difficult to compare the present study's findings to Chaudron's, because the 5 studies he examined all included content errors, unlike the present study; these consistently received a high proportion of feedback.

${ }^{10}$ Although they received corrective feedback at a lower rate $(56 \%)$, grammatical errors accounted for the highest proportion of corrective feedback moves in the database, due to their frequency. In absolute numbers, more grammatical errors received feedback than any other error type, thus revealing at least 
some degree of perseverance in combination with selectivity, if not consistency.

${ }^{11}$ The 3 explicit corrections following grammatical errors led to 3 repairs and the 13 explicit corrections following phonological errors led to 10 repairs, whereas the 10 explicit corrections following lexical errors led to only 3 repairs. In each case, however, the repairs simply involved repetition of the teacher's explicitly provided model.

${ }^{12}$ One reviewer of this article pointed out that reading aloud is not a communicative activity that focuses on content. However, we found that teachers frequently used a variety of texts to present content and asked individual students to read aloud before the information was discussed or classified.

\section{References}

Allen, P., Swain, M., Harley, B., \& Cummins, J. (1990). Aspects of classroom treatment: Toward a more comprehensive view of second language education. In B. Harley, P. Allen, J. Cummins, \& M. Swain (Eds.), The development of bilingual proficiency (pp. 57-81). Cambridge, UK: Cambridge University Press.

Allwright, D. (1975). Problems in the study of the language teacher's treatment of learner error. In M. Burt \& H. Dulay (Eds.), New directions in second language learning, teaching and bilingual education: On TESOL '75 (pp. 96-109). Washington: TESOL.

Allwright, D. (1984). Why don't learners learn what teachers teach? The interaction hypothesis. In D. Singleton \& D. Little (Eds.), Language learning in formal and informal contexts (pp. 3-18). Dublin: Irish Association for Applied Linguistics.

Allwright, D., \& Bailey, K. (1991). Focus on the language classroom. Cambridge, UK: Cambridge University Press.

Austin, J. (1962). How to do things with words. Oxford, UK: Oxford University Press.

Calvé, P. (1992). Corriger ou ne pas corriger, là n'est pas la question. The Canadian Modern Language Review, 48, 458-471.

Carroll, S., \& Swain, M. (1993). Explicit and implicit negative feedback: An empirical study of the learning of linguistic generalizations. Studies in Second Language Acquisition, 15, 357-386.

Chaudron, C. (1977). A descriptive model of discourse in the corrective treatment of learners' errors. Language Learning, 27, 29-46.

Chaudron, C. (1986). Teachers' priorities in correcting learners' errors in French immersion classes. In R. Day (Ed.), Talking to learn (pp. 64-84). Rowley, MA: Newbury House. 
Chaudron, C. (1988). Second language classrooms. New York: Cambridge University Press.

Cook, G. (1989). Discourse. Oxford, UK: Oxford University Press.

Corder, S. P. (1967). The significance of learners' errors. International Review of Applied Linguistics, 4, 161-170.

de Bot, K. (1996). The psycholinguistics of the output hypothesis. Language Learning, 46, 529-555.

Doughty, C. (1994). Finetuning of feedback by competent speakers to language learners. In J. Alatis (Ed.), Strategic interaction and language acquisition: Theory, practice, and research. GURT 1993 (pp. 96-108). Washington: Georgetown University Press.

Doughty, C., \& Varela, E. (1998). Communicative focus on form. In C. Doughty \& J. Williams (Eds.), Focus on form in classroom second language acquisition (pp. 114-138). New York: Cambridge University Press.

Ellis, N. (1995). Consciousness in second language acquisition: A review of field studies and laboratory experiments. Language Awareness, 4, 123-146.

Ellis, R. (1995). Uptake as language awareness. Language Awareness, 4, $147-159$.

Fanselow, J. (1977). The treatment of error in oral work. Foreign Language Annals, 10, 583-593.

Fazio, L., \& Lyster, R. (1997). COLT comparisons of immersion and submersion classrooms. Manuscript submitted for publication.

Gass, S. (1988). Integrating research areas: A framework for second language studies. Applied Linguistics, 9, 198-217.

Gass, S., \& Varonis, E. (1994). Input, interaction, and second language production. Studies in Second Language Acquisition, 16, 283-302.

Harley, B. (1993). Instructional stategies and SLA in early French immersion. Studies in Second Language Acquisition, 15, 245-260.

Harley, B. (1994). Appealing to consciousness in the L2 classroom. AILA Review, 11, 57-68.

Hendrickson, J. (1978). Error correction in foreign language teaching: Recent theory, research, and practice. Modern Language Journal, 62, 387-398.

Hulstijn, J. (1990). A comparison between the information-processing and the analysis/control approaches to language learning. Applied Linguistics, 11, $30-45$.

Lightbown, P. M. (1991). What have we here? Some observations on the role of instruction in second language acquisition. In R. Phillipson, E. Kellerman, L. Selinker, M. Sharwood Smith, \& M. Swain (Eds.), Foreign/second language pedagogy research: A commemorative volume for Claus Færch (pp. 197-212). Clevedon, UK: Multilingual Matters. 
Lightbown, P. M., \& Spada, N. (1990). Focus-on-form and corrective feedback in communicative language teaching: Effects on second language learning. Studies in Second Language Acquisition, 12, 429-448.

Long, M. (1977). Teacher feedback on learner error: Mapping cognitions. In H. D. Brown, C. A. Yorio, \& R. H. Crymes (Eds.), On TESOL '77 (pp. 278-293). Washington: TESOL.

Long, M. (1996). The role of the linguistic environment in second language acquisition. In W. C. Ritchie \& T. K. Bhatia (Eds.), Handbook of language acquisition: Vol. 2. Second language acquisition (pp. 413-468). New York: Academic Press.

Long, M., Inagaki, S., \& Ortega, L. (in press). The role of implicit negative evidence in SLA:Models and recasts in Japanese and Spanish. The Modern Language Journal.

Lyster, R. (1994). La négociation de la forme: Stratégie analytique en classe d'immersion. The Canadian Modern Language Review, 50, 447-465.

Lyster, R. (1998). Recasts, repetition, and ambiguity in L2 classroom discourse. Studies in Second Language Acquisition, 20, 51-81.

Lyster, R., \& Ranta, L. (1997). Corrective feedback and learner uptake: Negotiation of form in communicative classrooms. Studies in Second Language Acquisition, 19, 37-66.

Mackey, A., \& Philp, J. (in press). Conversational interaction and second language development: Recasts, responses, and red herrings. The Modern Language Journal.

Marcus, G. (1993). Negative evidence in language acquisition. Cognition, 46, 53-85.

McLaughlin, B. (1990). Restructuring. Applied Linguistics, 11, 113-128.

Morgan, J., Bonamo, K., \& Travis, L. (1995). Negative evidence on negative evidence. Developmental Psychology, 31, 180-197.

Netten, J. (1991). Towards a more language oriented second language classroom. In L. Malavé \& G. Duquette (Eds.), Language, culture and cognition (pp. 284-304). Clevedon, UK: Multilingual Matters.

Nobuyoshi, J., \& Ellis, R. (1993). Focused communication tasks and second language acquisition. ELT Journal, 47, 203-210.

Pica, T. (1988). Interlanguage adjustments as an outcome of NS-NNS negotiated interaction. Language Learning, 38, 45-73.

Pica, T., Holliday, L., Lewis, N., \& Morgenthaler, L. (1989). Comprehensible output as an outcome of linguistic demands on the learner. Studies in Second Language Acquisition, 11, 63-90.

Roberts, M. (1995). Awareness and the efficacy of error correction. In R. Schmidt (Ed.), Attention and awareness in foreign language learning (Tech. Rep. No. 9, pp. 162-182). Honolulu: University of Hawai'i, Second Language Teaching and Curriculum Center. 
Schachter, J. (1983). Nutritional needs of language learners. In M. Clarke \& J. Handscombe (Eds.), On TESOL '82: Pacific perspectives on learning and teaching (pp. 175-189). Washington: TESOL.

Schegloff, E., Jefferson, G., \& Sacks, H. (1977). The preference for self-correction in the organization of repair in conversation. Language, 53, 361-382.

Seedhouse, P. (1997). The case of the missing "no": The relationship between pedagogy and interaction. Language Learning, 47, 547-583.

Slimani, A. (1992). Evaluation of classroom interaction. In C. Anderson \& A. Beretta (Eds.), Evaluating second language education (pp. 197-221). Cambridge, UK: Cambridge University Press.

Spada, N. (1997). Form-focussed instruction and second language acquisition: A review of classroom and laboratory research. Language Teaching, 29, $1-15$.

Spada, N., \& Fröhlich, M. (1995). COLT: Communicative Orientation of Language Teaching observation scheme. Coding conventions and applications. Sydney, Australia: National Centre for English Language Teaching and Research, Macquarie University.

Spada, N., \& Lightbown, P. M. (1993). Instruction and the development of questions in L2 classrooms. Studies in Second Language Acquisition, 15, $205-224$.

Swain, M. (1985). Communicative competence: Some roles of comprehensible input and comprehensible output in its development. In S. Gass \& C. Madden (Eds.), Input in second language acquisition (pp. 235-253). Rowley, MA: Newbury House.

Swain, M. (1988). Manipulating and complementing content teaching to maximize second language learning. TESL Canada Journal, 6, 68-83.

Swain, M. (1993). The output hypothesis: Just speaking and writing aren't enough. The Canadian Modern Language Review, 50, 158-164.

Swain, M. (1995). Three functions of output in second language learning. In G. Cook \& B. Seidlhofer (Eds.), Principles and practice in applied linguistics: Studies in honour of H. G. Widdowson (pp. 125-144). Oxford, UK: Oxford University Press.

Thornton, I., \& Pienemann, M. (1994). COALA: Computer-aided linguistic analysis. Sydney, Australia: Language Acquisition Research Centre.

Tomasello, M., \& Herron, C. (1988). Down the Garden Path: Inducing and correcting overgeneralization errors in the foreign language classroom. Applied Psycholinguistics, 9, 237-246.

Tomasello, M., \& Herron, C. (1989). Feedback for language transfer errors: The Garden Path technique. Studies in Second Language Acquisition, 11, 385-395.

Towell, R., Hawkins, R., \& Bazergui, N. (1996). The development of fluency in advanced learners of French. Applied Linguistics, 17, 84-119. 
van Lier, L. (1988). The classroom and the language learner. London: Longman.

Vigil, N., \& Oller, J. (1976). Rule fossilization: A tentative model. Language Learning, 26, 281-295.

\section{Appendix A}

\section{Database}

4 teachers

13 French Language Arts lessons ( $467 \mathrm{~min}=7.8 \mathrm{hrs}$.)

14 subject matter lessons-science, social studies, math (633 min $=10.5 \mathrm{hrs}$.)

27 lessons totaling 1,100 minutes or 18.3 hours

School Board A-Early total immersion

Teacher 3 (Grade 4)-11 lessons (340 $\mathrm{min})$.

1. Jan. 16 Language arts-prereading activity about meteorology $20 \mathrm{~min}$

2. Jan. 16 Language arts-reading ( $L a$ météorologie en folie)

$30 \mathrm{~min}$

3. Jan. 16 Science-mammals' means of adapting to environment

$65 \mathrm{~min}$

4. Jan. 16 Math-geometric translations

$40 \mathrm{~min}$

5. Jan. 30 Social studies - the first settlers

$15 \min$

6. Feb. 6 Language arts-reading (Les bestsellers)

$45 \min$

7. Mar. 6 Language arts-writing letters to companies

$15 \mathrm{~min}$

8. Mar. 8 Language arts-discussion (paying youth for chores) 
9. Mar. 20 Language arts-discussion about vacation

$25 \min$

10. Mar. 20 Language arts-reading (Camomille la sorcière)

$20 \mathrm{~min}$

11. Mar. 29 Language arts-students' poetry

$45 \mathrm{~min}$

School Board B-Mid-immersion

Teacher 4 (Grades 4/5)-4 lessons (250 min).

1. Mar. 17 Science-students present science experiments

$50 \mathrm{~min}$

2. Mar. 17 Language arts-role plays to reenact story

$85 \min$

3. Mar. 24 Math-measurement and estimation

$40 \mathrm{~min}$

4. Mar. 31 Social studies-discovery of North America

$75 \mathrm{~min}$

Teacher 5 (Grade 4)-8 lessons (325 min).

1. Mar. 14 Language arts-classified ads

$50 \mathrm{~min}$

2. Mar. 21 Language arts-discussion about long weekend

$12 \mathrm{~min}$

3. Mar. 21 Science-zoo animals

$45 \mathrm{~min}$

4. Mar. 28 Science-animals (habitat, sounds, movement)

$58 \mathrm{~min}$

5. Apr. 4 Science-bread and cereal food group $50 \mathrm{~min}$

6. Apr. 11 Science-animals (oral presentations) $35 \mathrm{~min}$

7. Apr. 11 Social studies-manufacturing of Whippet cookies

$15 \min$

8. Apr. 25 Science-water cycle $60 \mathrm{~min}$ 
Teacher 6 (Grade 4)-4 lessons (185 $\mathrm{min})$.

1. Apr. 3 Language arts-reading (La cabane à sucre)

$55 \mathrm{~min}$

2. Apr. 10 Language arts-reading (Easter)

$45 \mathrm{~min}$

3. Apr. 27 Science-animals

$50 \mathrm{~min}$

4. May 11 Science-the field mouse and review of body parts

$35 \mathrm{~min}$

\section{Appendix B}

Negotiation of form.

(1) (T3-Science-January 16)

St: $\quad$ Eh ...elle fait... Ben y a un jet de parfum qui sent pas très bon... [Lexical error]

"Uh ... she does... Well there's a stream of perfume that doesn't smell very nice..."

T3: Alors un jet de parfum on va appeler ça un ...? [Elicitation]

"So a stream of perfume, we'll call that a ...?"

Stdif: Liquide puant. [Repair-peer]

"Smelly liquid."

T3: Un liquide puant [Approval] aussi on appelle ça un liquide qui a pas une bonne odeur, comment on appelle ça? [Topic continuation]

"A smelly liquid, we also call that a liquid with an unpleasant odor, what do we call that?"

(2) (T5-Science-March 28)

St: $\quad E u h m$, le, le éléphant. Le éléphant gronde. [Phonological error] "Uhm, the, the elephant. The elephant growls."

T5: Est-ce qu'on dit le éléphant? [Metalinguistic clue] "Do we say the elephant?"

Sts: Non. [Needs repair] "No." 
T5: Ça commence avec une voyelle. Est-ce qu'on peut dire le éléphant? [Metalinguistic clue] "It starts with a vowel. Can we say the elephant?"

Sts: Non. [Needs repair]

"No."

T5: Qu'est-ce qu'on va dire? [Elicitation] "What are we going to say?"

St: $\quad I l .[$ Needs repair] "He."

T5: Non. [Metalingustic clue] "No."

St: L'éléphant. [Repair-self] "The elephant."

T5: Léléphant. Alors, on va enlever le " $e$ " du déterminant, pis on va mettre un apostrophe. On va dire "l'éléphant" [Approval] et l'éléphant, on dit pas vraiment qu'il gronde. $Y$ a un autre verbe pour dire ce que l'éléphant fait. [Topic continuation]

"The elephant. So, we remove the "e" from the determiner, and then we put in an apostrophe. We then say the elephant, and we don't say that the elephant growls. There's another verb to say what the elephant does."

Recast.

(3) (T3-Science-January 16)

St: Les tuent. [Grammatical error]

Kill them.

T5: Ils les tuent. [Recast] Pourquoi ils les tuent? [Topic continuation]

They kill them. Why do they kill them?

(4) (T4-Language Arts-March 17)

St: $\quad$ Parce qu'il est froid. [Lexical error]

"Because he's cold"

T4: Il fait froid. [Recast]

"It's cold." 
Stdif: Comment est-ce qu'on va aller chercher ça? [Topic continuation]

"How are we going to go and get that?"

Explicit correction.

(5) (T6-Science-April 27)

St: La note pour le "shot". [L1]

"The note for the shot."

T6: Oh, pour la, oh, pour ça. Tu veux dire pour la piqûre. Piqûre. [Explicit] Oui? [Topic continuation] "Oh, for the, for that. You mean for the needle. Needle. Yes?"

(6) (T4-Language Arts-March 17)

St: $\quad[. .$.$] le renard gris, le loup, le coyote, le bison et la$ gr ... groue. [Phonological error]

"[. . .] the gray fox, the wolf, the coyote, the bison and the cr... crane."

T4: Et la grue. On dit "grue". [Explicit]

"And the crane. We say 'crane.'”

St: Grue. [Repair-repetition]

"Crane."

T4: Tout le monde dit "grue". [Approval]

"Everyone say 'crane." 